\title{
HUBUNGAN ANTARA DUKUNGAN KELUARGA DENGAN MANAJEMEN DIRI PADA PENDERITA DIABETES MELLITUS DI WILAYAH KERJA PUSKESMAS ALANG-ALANG LEBAR PALEMBANG
}

\author{
Dewi Rury Arindari ${ }^{1}$, Rina Lestari ${ }^{2}$ \\ 1. Dosen STIK Siti Khadijah Palembang \\ Email: dewirury2013@gmail.com
}

\begin{abstract}
ABSTRAK
Penyakit kronik merupakan suatu kondisi medis atau masalah kesehatan yang berkaitan dengan gejala-gejala atau kecacatan yang membutuhkan penatalaksanaan jangka panjang. Data International Diabetes Federation (IDF) tahun 2013, diketahui bahwa Diabetes Mellitus menyebabkan 5,1 juta kematian, dengan penderita meninggal setiap 6 detik. Diabetes Mellitus menghabiskan dana kesehatan setidaknya 548 juta USD dan sekitar $11 \%$ dari total yang dihabiskan diberikan kepada penderita dewasa dalam rentang usia 26-45 tahun, Diabetes mellitus biasanya didiagnosis pada orang dewasa usia 40 atau lebih. Semakin meluasnya pola makan dan gaya hidup tidak sehat, mengakibatkan ratarata usia penderita diabetes mellitus kini bergeser semakin muda. Tujuan penelitian ini diketahuinya hubungan antara dukungan keluarga dengan manajemen diri pada penderita Diabetes Mellitus di Wilayah Kerja Puskesmas Alang-Alang Lebar Palembang. Rancangan penelitian ini menggunakan desain cross sectional. Analisa univariat dan bivariat dengan chi square digunakan untuk menganalisa data. Populasi dalam penelitian adalah penderita Diabetes Mellitus yang berkunjung ke Puskesmas Alang-Alang Lebar dan tinggal dengan keluarga minimal tiga bulan terakhir, serta telah didiagnosa dokter menderita Diabetes Mellitus dalam 6 bulan terakhir. Besaran sampel dalam penelitian adalah 51 responden dengan teknik Purposive Sampling. Hasil penelitian menunjukkan bahwa ada hubungan antara dukungan keluarga dengan manajemen diri penderita Diabetes Mellitus dengan dengan $\rho$ value $=0,01$. Diharapkan perawat Puskesmas Alang-Alang Lebar Palembang dapat memberikan pendidikan kesehatan secara rutin tentang pentingnya keluarga terhadap manajemen diri penderita Diabetes Mellitus.
\end{abstract}

Kata Kunci : Dukungan Keluarga, Manajemen Diri, Diabetes Mellitus

Daftar Pustaka : 16 (2010-2016)

\section{Pendahuluan}

Penyakit kronik adalah suatu kondisi dimana terjadi keterbatasan pada kemampuan fisik, psikologis atau kognitif dalam melakukan fungsi harian atau kondisi yang memerlukan pengobatan khusus dan terjadi dalam beberapa bulan. Diabetes Mellitus bukan merupakan suatu penyakit menular dan termasuk ke dalam penyakit long term care yang masih menjadi trend dan issue dalam keperawatan keluarga saat ini (Putri, dkk. 2013)

Diabetes Mellitus adalah penyakit yang disebabkan oleh gangguan-gangguan pada penyerapan gula darah oleh tubuh, sehingga membuat kadarnya di dalam darah menjadi tinggi. Tingginya kadar gula di dalam darah ini dapat menyebabkan terjadi komplikasi terhadap kesehatan lainnya (Susanto, 2013).

Komplikasi penyakit diabetes mellitus diklasifikasikan menjadi dua, yaitu komplikasi yang bersifat akut dan kronis (menahun). Komplikasi akut merupakan komplikasi yang harus ditindak cepat atau memerlukan pertolongan dengan segera. Adapun komplikasi kronis merupakan komplikasi yang timbul setelah penderita mengidap Diabetes Mellitus selama 5-10 tahun atau lebih. (Kariadi, 2013).

Dampak psikologis yang terjadi pada penderita dengan Diabetes seperti kecemasan, kemarahan, berduka, malu, rasa bersalah, 
hilang harapan, depresi, kesepian, tidak berdaya (Potter \& Perry 2010), ditambah lagi penderita dapat menjadi pasif, merasa tidak nyaman, bingung dan merasa menderita (Purwaningsih \& Karlina, 2012).

Pengelolahan pengobatan dan intervensi pola hidup bagi penderita diabetes mellitus harus tetap dijalankan seumur hidupnya, hal ini akan berimplikasi pada pengaturan pembiayaan kesehatan yang dikeluarkan penderita guna mempertahankan kondisi kesehatan selama menderita penyakit tersebut. Produktifitas dan kualitas hidup penderita tidak pada kondisi normal, hal ini akan berdampak pada beban ekonomi individu, keluarga, maupun Negara dalam mewujudkan derajat kesehatan masyarakat yang optimal (Makaminan, 2014).

Diabetes adalah penyakit kronis yang dapat dikendalikan dengan cara pengaturan pola makan, aktivitas fisik, pemantauan glukosa dan minum obat sesuai anjuran dokter. Penatalaksanaan pengobatan dan penanganan difokuskan pada gaya hidup dan aktivitas fisik. Pengontrolan nilai kadar gula dalam darah adalah menjadi kunci program pengobatan. Penatalaksanaan yang dapat dilakukan oleh perawat pada penderita diabetes mellitus yaitu dengan Manajemen Diri sebagai faktor internal, salah satu faktor yang dapat mempengaruhi dari pelaksanaan manajemen diri adalah Dukungan Keluarga (Indonesian Children, 2010).

Manajemen diri pada penderita Diabetes Mellitus merupakan seperangkat perilaku yang dilakukan oleh individu dengan diabetes untuk mengelola kondisi klien, termasuk minum obat, mengatur diet, melakukan latihan fisik, pemantauan glukosa darah mandiri, dan mempertahankan perawatan kaki. Manajemen diri pada diabetes juga didefinisikan sebagai perilaku manajemen diri yang mencakup pengaturan pola makan, olahraga, pemantauan glukosa darah secara mandiri, dan minum obat, yang secara keseluruhan berhubungan dengan perbaikan yang signifikan dalam mengontrol status metabolik (Hunt et al, 2012 dalam Astuti, 2014).

Manajemen diri merupakan kemampuan untuk mengenali, mengolah dirinya (secara fisik, emosi, emosi, pikiran, jiwa, dan spiritual) sehingga dia mampu mengelola orang lain dan berbagai sumber daya sehingga menciptakan realitas kehidupan sesuai dengan misi dan tujuan hidupnya (Wahyuningsih, 2014).

Menurut survei yang dilakukan oleh organisasi kesehatan dunia (WHO), Jumlah penderita Diabetes Melitus di Indonesia pada tahun 2015 menempati peringkat ke tujuh tertinggi di dunia dengan jumlah estimasi sebesar 10 juta. Sedangkan pada tahun 2040 diperkirakan jumlahnya akan menjadi 642 juta. (IDF Atlas, 2015).

Menurut data Perkumpulan Endokrinologi (PERKENI), 2015, jumlah penderita Diabetes Mellitus di Indonesia telah mencapai 9,1 juta orang. Indonesia mengalami peningkatan kasus Diabetes Mellitus dengan menduduki peringkat kelima diantara negaranegara dengan jumah penderita Diabetes Mellitus terbanyak dunia (Rudjiyanto, 2015).

Menurut data dari Profil Kementerian Kesehatan Republik Indonesia, didapatkan bahwa jumlah penderita Diabetes Mellitus di Provinsi Sumatera Selatan pada tahun 2014 sebanyak 3.173 orang hampir tiga kali lipat mengalami peningkatan pada tahun 2015 sebanyak 9.169 orang, dan pada tahun 2016 mengalami peningkatan kembali sebanyak 10.871 orang (Kementerian Kesehatan RI, 2016).

Kecamatan Alang-Alang Lebar merupakan urutan ketiga terbanyak penderita Diabetes Mellitus di Kota Palembang. Kecamatan Alang-Alang Lebar memiliki 2 Puskesmas yaitu Puskesmas Punti kayu dan Alang-Alang Lebar . Data dari Puskesmas Alang-Alang Lebar Palembang pada tahun 2015 terdiri dari 57 penderita Diabetes Mellitus, kemudian meningkat pada tahun 2016 sebanyak 63 penderita, dan terjadi peningkatan kembali pada tahun 2017 menjadi 106 penderita (Dinkes Kota Palembang, 2017).

Berdasarkan data Dinas Kesehatan Palembang tahun 2017, Diketahui bahwa 75\% penderita Diabetes Mellitus dalam wilayah kerja Kecamatan Alang-Alang Lebar berasal dari Puskesmas Alang-Alang Lebar yaitu sebanyak 162 penderita diabetes. Selanjutnya pada tahun 2018 terhitung bulan januari-maret lebih dari $50 \%$ penderita Diabetes Mellitus berada dalam wilayah kerja Puskesmas AlangAlang Lebar.

Berdasarkan data IDF (International Diabetes Federation) (2013), diketahui bahwa Diabetes Mellitus menyebabkan 5,1 juta kematian, dimana penderita meninggal setiap 6 detik akibat Diabetes Mellitus. Kemudian 
Diabetes Mellitus juga menghabiskan dana kesehatan setidaknya 548 juta USD dan sekitar $11 \%$ dari total yang dihabiskan diberikan kepada penderita dewasa dalam rentang usia 26-45 tahun, Diabetes mellitus biasanya di diagnosis pada orang dewasa berusia 40 dan lebih tua. Diabetes mellitus berkembang cepat disekitar usia 45-64 tahun, dan semakin meningkat pesat lagi berusia 65 keatas. Semakin meluasnya pola makan dan gaya hidup tidak sehat, rata-rata usia terkena diabetes mellitus kini bergeser semakin muda.

Seorang dengan penyakit kronis akan mengalami berbagai macam perubahan yang terjadi pada dirinya, sehingga dalam hal ini keluarga berperan dalam mengontrol kesehatan keluarganya yang mengalami Diabetes.

Keluarga merupakan bagian terpenting bagi semua orang. Begitu pula bagi penderita Diabetes mellitus. Disadari atau tidak, saat seseorang mengalami diabetes mellitus maka penderita akan mengalami masa-masa sulit. Penderita harus mulai berbenah diri, mulai mengontrol pola makan dan aktifitas. Hal tersebut pasti sangat membutuhkan bantuan dari orang sekitar terutama keluarga, dengan menceritakan kondisi diabetes mellitus pada orang terdekat, maka akan membantu dalam kontrol diet dan program pengobatan (Wardani, et al, 2014)

Dukungan keluarga merupakan dukungan diperoleh dari orang lain yang dapat dipercaya, sehingga seseorang akan tahu bahwa ada orang lain yang memperhatikan, menghargai, dan mencintainya. Dukungan keluarga menjadikan penderita diabetes mellitus mampu dalam meningkatkan kesehatan dan adaptasi dalam kehidupan (Sasih, 2015).

Dukungan keluarga memiliki 4 dimensi dukungan yaitu dukungan emosional (perasaan empati dan perhatian), dukungan penghargaan (membuat seseorang merasa berharga), dukungan Instrumental (bersifat nyata atau bantuan langsung), dan dukungan informasi (percakapan atau umpan balik) (Sasih, 2015).

Berdasarkan studi Literature yang dilakukan peneliti, masih ditemukan inkonsistensi dalam hasil penelitian. Studi pendahuluan oleh Arisuswita (2016), dan Siregar (2014) menyatakan bahwa ada hubungan antara dukungan keluarga dengan manajemen diri, sedangkan hasil penelitian Hasanat (2015) menyatakan bahwa tidak ada hubungan antara dukungan keluarga dengan manajemen diri.

Berdasarkan uraian diatas, Peneliti tertarik untuk melakukan penelitian tentang hubungan antara dukungan keluarga dengan manajemen diri pada penderita Diabetes Mellitus di Wilayah Kerja Puskesmas AlangAlang Lebar Palembang Tahun 2018.

\section{METODE PENELITIAN \\ Desain Penelitian}

Desain yang digunakan dalam penelitian ini adalah cross sectional (potong lintang), dimana pengukuran terhadap dukungan keluarga dan manajemen diri dilakukan dalam waktu bersamaan.

\section{Populasi dan Sampel \\ 1. Populasi}

Populasi dalam penelitian ini adalah penderita Diabetes Mellitus yang berkunjung ke Puskesmas Alang-Alang Lebar Palembang Tahun 2017 sebanyak 106 penderita.

\section{Sampel}

Sampel dalam penelitian ini adalah Penderita Diabetes Mellitus yang berkunjung ke Puskesmas Alang-Alang Lebar yang tinggal dengan keluarga minimal tiga bulan terakhir, dan telah didiagnosa dokter menderita Diabetes Mellitus dalam 6 bulan terakhir. Besaran sampel adalah sebanyak 51 responden dengan teknik Purposive Sampling.

\section{Tempat dan Waktu Penelitian}

Penelitian ini telah dilakukan di Wilayah Kerja Puskesmas Alang-Alang Lebar pada Juli 2018.

\section{Hasil Penelitian}

1. Analisis Univariat

\section{a. Karakteristik Responden}

Tabel 4.1

Karakteristik Responden pada Penderita Diabetes Mellitus dI Wilayah Kerja Puskesmas Alang-Alang Lebar Palembang

\begin{tabular}{|c|l|c|c|}
\hline No & \multicolumn{1}{|c|}{$\begin{array}{c}\text { Karakteristik } \\
\text { Responden }\end{array}$} & $\begin{array}{c}\text { Jumlah } \\
\text { (n) }\end{array}$ & $\%$ \\
\hline 1. & Jenis Kelamin & & \\
& Laki-laki & 21 & $41,1 \%$ \\
& Perempuan & 30 & $58,9 \%$ \\
\hline 2. & Usia & & \\
\hline
\end{tabular}




\begin{tabular}{|c|l|c|c|}
\hline & Dewasa Muda & 16 & $31,4 \%$ \\
& $(26-40)$ & 35 & $68,6 \%$ \\
& Dewasa Akhir & & \\
& $(41-55)$ & & \\
\hline 3. & Pendidikan & & \\
& SD & 17 & $33,5 \%$ \\
& SMP & 23 & $45 \%$ \\
& SMA & 11 & $21,5 \%$ \\
\hline 4. & Pekerjaan & & \\
& Pedagang & 21 & $41,2 \%$ \\
& Petani/Buruh & 19 & $37,3 \%$ \\
& Pegawai Swasta & 11 & $21,5 \%$ \\
\hline 5. & Lama Menderita & & \\
& 7 Bulan & 9 & $17,2 \%$ \\
& 9 Bulan & 11 & $21 \%$ \\
& 10 Bulan & 6 & $11,1 \%$ \\
& 11 Bulan & 20 & $39 \%$ \\
& 1 Tahun & 5 & $9 \%$ \\
& & & \\
\hline
\end{tabular}

b. Dukungan Keluarga

Tabel 4.2

Distribusi Responden Berdasarkan

Dukungan Keluarga di Wilayah Kerja Puskesmas Alang-Alang Lebar Tahun 2018

\begin{tabular}{|c|c|c|c|}
\hline NO & $\begin{array}{c}\text { Dukungan } \\
\text { Keluarga }\end{array}$ & $\begin{array}{c}\text { Jumlah } \\
\text { (n) }\end{array}$ & $\mathbf{\%}$ \\
\hline 1. & Baik & 23 & 45,1 \\
\hline 2. & Kurang Baik & 28 & 54,9 \\
\hline \multicolumn{2}{|c|}{ Jumlah } & $\mathbf{5 1}$ & $\mathbf{1 0 0}$ \\
\hline
\end{tabular}

\section{c. Manajemen Diri}

Tabel 4.3

Distribusi Responden Berdasarkan Manajemen Diri Penderita Diabetes Mellitus di Wilayah Kerja Puskesmas Alang-Alang Lebar Palembang Tahun 2018

\begin{tabular}{|c|c|c|c|}
\hline No & $\begin{array}{c}\text { Manajemen } \\
\text { Diri }\end{array}$ & $\begin{array}{c}\text { Jumlah } \\
\text { (n) }\end{array}$ & \% \\
\hline 1. & Baik & 18 & 35,3 \\
\hline 2. & Kurang Baik & 33 & 64,7 \\
\hline \multicolumn{2}{r|}{ Jumlah } & $\mathbf{5 1}$ & $\mathbf{1 0 0}$ \\
\hline
\end{tabular}

\section{Analisis Bivariat}

Tabel 4.4

Hubungan antara Dukungan Keluarga dengan Manajemen Diri pada Penderita Diabetes Mellitus di Wilayah Kerja Puskesmas Alang-Alang Lebar Palembang Tahun 2018.

\begin{tabular}{|c|c|c|c|c|c|c|}
\hline \multirow{3}{*}{$\begin{array}{c}\text { Dukungan } \\
\text { Keluarga }\end{array}$} & \multicolumn{4}{|c|}{ Manajemen Diri } & \multirow{3}{*}{$\begin{array}{c}\text { p } \\
\text { Value } \\
\text { Phi }\end{array}$} & \multirow{3}{*}{$\begin{array}{l}\mathbf{O} \\
\mathbf{R}\end{array}$} \\
\hline & \multicolumn{2}{|c|}{ Baik } & \multicolumn{2}{|c|}{$\begin{array}{c}\text { Kurang } \\
\text { Baik }\end{array}$} & & \\
\hline & $\mathrm{n}$ & $\%$ & $\mathrm{n}$ & $\%$ & & \\
\hline Baik & 13 & 56,5 & 10 & 43,5 & & \\
\hline $\begin{array}{c}\text { Kurang } \\
\text { Baik }\end{array}$ & 5 & 17,9 & 23 & 82,1 & $\begin{array}{c}0,403= \\
40 \%\end{array}$ & $\begin{array}{l}5, \\
9 \\
8\end{array}$ \\
\hline
\end{tabular}

Berdasarkan hasil uji statistik ChiSquare didapatkan $\rho$ value $0,01<\alpha(0,05)$, hal ini menunjukan bahwa ada hubungan yang bermakna secara statistik dengan kekuatan hubungan yang positif sedang $(\mathrm{Phi}=0,403)$ antara dukungan keluarga dengan manajemen diri pada penderita diabetes mellitus di Wilayah Kerja Puskesmas Alang-Alang Lebar Palembang Tahun 2018. Hasil analisis juga di dapatkan nilai $\mathrm{OR}=5,98$ hal ini berarti dukungan keluarga yang baik berpeluang 5,98 memiliki manajemen diri yang baik dibandingkan dengan dukungan keluarga yang kurang baik.

\section{Pembahasan}

\section{Pembahasan Univariat}

\section{a. Dukungan Keluarga}

Berdasarkan hasil analisa univariat dari 51 responden, dukungan keluarga kurang baik lebih banyak daripada dukungan keluarga baik yaitu sebanyak 28 responden (54,9\%).

Dukungan keluarga merupakan suatu proses hubungan antara keluarga dan lingkungan sosialnya yang dapat diakses oleh keluarga dan bersifat mendukung serta memberikan pertolongan kepada anggota keluarga yang lain. Dukungan keluarga ialah suatu bentuk pemberian dukungan terhadap anggota keluarga lain yang mengalami permasalahan, meliputi dukungan pemeliharaan, emosional 
untuk mencapai kesejahteraan anggota keluarga dan memenuhi kebutuhan psikososial (Friedman, 2010).

Dukungan keluarga dipengaruhi oleh beberapa faktor termasuk dari karakteristik responden. Menurut hasil penelitian di Puskesmas Alang-alang Lebar diketahui bahwa sebagian besar memiliki pendidikan dibawah SMA (Rendah), hal ini dapat menjadi salah satu penyebab keluarga kurang memahami informasi tentang penyakit diabetes mellitus dan bahaya yang mungkin timbul. Penderita merasa cukup apabila sudah berobat ke Puskesmas sehingga keluarga kurang memperhatikan bagaimana cara menangani penderita Diabetes Mellitus, utamanya tentang diet yang harus dijalani.

Menurut hasil penelitian juga diketahui bahwa lebih dari setengah jumlah total responden bekerja sebagai petani, pedagang dan buruh. Hal ini menyebabkan keluarga kurang memiliki kesempatan dan waktu untuk memberikan dukungan langsung kepada penderita diabetes mellitus dalam upaya manajemen diri

\section{b. Manajemen Diri}

Berdasarkan hasil analisa univariat dari 51 responden, manajemen diri penderita Diabetes Mellitus yang kurang baik lebih banyak daripada manajemen diri baik yaitu sebanyak 33 responden $(64,7 \%)$.

Manajemen diri adalah suatu proses berkelanjutan yang dilakukan untuk memfasilitasi pengetahuan, keterampilan, dan kemampuan penderita diabetes mellitus untuk melakukan perawatan mandiri. (Funnell, et. al. 2011)

Manajemen diri pada diabetes juga didefinisikan sebagai suatu perilaku manajemen diri yang meliputi pengaturan pola makan, olahraga, pemantauan glukosa darah secara mandiri, dan minum obat yang signifikan dalam mengontrol status metabolik (Hunt et al., 2012 dalam Fatimah, 2016).

Manajemen diri yang kurang baik pada responden penderita Diabetes Mellitus di Wilayah Kerja Puskesmas
Alang-Alang Lebar Palembang dapat dipengaruhi dari pendidikan responden yang lebih banyak dibawah tingkat SMA (Rendah) sehingga sulit untuk memahami bahaya yang dapat ditimbulkan akibat tidak mematuhi tatalaksana diabetes mellitus.

Hasil penelitian menunjukkan bahwa masih banyak penderita Diabetes Mellitus yang kurang mengetahui tentang pentingnya isi dari manajemen diri dan dukungan keluarga, sehingga penderita cenderung tidak menjalankan diet, olah raga dan minum obat teratur.

\section{Pembahasan Bivariat}

Berdasarkan hasil penelitian diketahui bahwa, manajemen diri kurang baik pada responden yang memiliki dukungan keluarga yang kurang baik lebih tinggi dibandingkan dengan responden yang memiliki dukungan keluarga yang baik yaitu 23 responden $(82,1 \%)$.

Berdasarkan Uji chi-square di dapatkan $\mathrm{p}$ value $0,01<\alpha(0,05)$, hal ini menunjukan bahwa ada hubungan yang bermakna antara dukungan keluarga dengan manajemen diri di wilayah kerja Puskesmas Alang-Alang Lebar Palembang Tahun 2018, dengan tingkat kekuatan hubungan yang positif sedang ( $\mathrm{Phi}=0,403$ )

Penelitian oleh Siregar (2014) menyebutkan adanya hubungan pengetahuan dan dukungan keluarga dengan kepatuhan penderita diabetes mellitus dalam manajemen diri. Pengobatan dan perawatan sangat sulit dicapai bagi seorang penderita diabetes. Pengetahuan dan dukungan keluarga merupakan dua hal yang dapat membantu kepatuhan penderita dalam proses perawatannya. Adanya dukungan dari keluarga dapat meningkatkan status kesehatan penderita.

Berdasarkan hasil penelitian, teori dan penelitian terkait yang ada, peneliti berasumsi, bahwa dukungan keluarga merupakan suatu dukungan atau bantuan penuh keluarga dalam bentuk memberikan bantuan tenaga, dana maupun menyediakan waktu untuk melayani dan mendengarkan keluarga yang sakit dalam mengungkapkan perasaan yang dialaminya, sehingga dapat membantu penderita mengambil keputusan dalam manajemen penyakitnya. 
SIMPULAN

Berdasarkan hasil penelitian yang dilakukan di Puskesmas Alang-alang Lebar Palembang Tahun 2018 diketahui bahwa :

1. Responden yang memiliki dukungan keluarga kurang baik lebih tinggi dibandingkan dengan dukungan keluarga baik yaitu 23 responden $(45,1 \%)$.

2. Responden yang memiliki manajemen diri kurang baik lebih tinggi dibandingkan dengan manajemen diri responden yang baik yaitu $33(64,7 \%)$.

3. Ada hubungan antara dukungan keluarga dengan manajemen diri pada penderita Diabetes Mellitus dengan $\rho$ value 0,010 .

\section{SARAN}

1. Bagi Puskesmas Alang-Alang Lebar Palembang

Diharapkan Puskesmas Alang-Alang Lebar dapat terus meningkatkan pengetahuan melalui penyuluhan kepada keluarga tentang cara memberikan dukungan kepada penderita Diabetes Mellitus.

2. Bagi Peneliti Selanjutnya

Diharapkan dapat meneliti keterkaitan variabel lain yang berhubungan dengan manajemen diri penderita Diabetes Mellitus menggunakan metode penelitian kualitatif guna mendapatkan informasi yang lebih mendalam.

\section{DAFTAR PUSTAKA}

Fatimah. 2016. Hubungan antara Faktor Personal dan Dukungan Keluarga dengan Manajemen Diri Penderita Diabetes Mellitus di Posbindu Wilayah Kerja Puskesmas Pisangan Kota Tangerang Selatan.

Hasdianah. 2012. Mengenal Diabetes Mellitus pada Orang Dewasa dan Anak-Anak dengan Solusi Herbal. Yogyakarta: Nuha Medika.

International Diabetes Federation. 2014. IDF Diabetes Atlas $7^{\text {th }}$ Edition. Brussels: International Diabetes Federation.
Diabetes Atlas $7^{\text {th }}$ Edition. Brussels: International Diabetes Federation.

JhonsonL \& Leny R. 2010. Keperawatan Keluarga Plus Contoh Askep Keluarga. Yogyakarta: Nuha Medika.

Kariadi, Ks, Sri Hartini. 2013. Diabetes Siapa Takut: Panduan Lengkap untuk Diabetis, Keluarganya, dan Profesional Medis. Bandung: KDT.

Dinas Kesehatan. 2016. Profil Data Penderita Diabetes Mellitus di Provinsi Sumatera Selatan Palembang. Palembang: Dinkes Palembang

Moore, Mary Courtney. 2012. Buku Pedoman Terapi Diet Dan Nutrisi. Jakarta: Hipokrates.

Notoadmojo. 2012. Metodelogi Penelitian Kesehatan. Jakarta: PT. Rineka Cipta.

-------. 2013. Metodelogi Penelitian Kesehatan. Jakarta: PT.Rineka Cipta.

Padila. 2012. Buku Ajar: Keperawatan Keluarga dilengkapi Aplikasi Kasus Askep Keluarga Terapi Herbal dan Terapi Modalitas. Yogyakarta: Nuha Medika.

Perkumpulan Endokrinologi Indonesia, 2012. Konsesus Pengendalian dan Pencegahan Diabetes Mellitus Tipe II di Indonesia. Jakarta: PERKENI.

Putri, Honesty Dkk. 2013. Hubungan Peran Keluarga dengan Pengendalian Kadar Gula Darah pada Pasien Diabetes Melitus di Wilayah Kerja Puskesmas Pauh Padang. Ners Jurnal Keperawatan, Vol.9, No.2

Rahmawati, Dkk. 2016. Pengaruh Program Diabetes Self-Management Education Terhadap Manajemen Diri Pada Penderita Diabetes Mellitus Tipe 2. ISNN, Vol.4, No.1

Siregar, Rinco. 2014. Hubungan Pengetahuan dan Dukungan Keluarga dengan Kepatuhan Penderita Diabetes Mellitus Dalam Manajemen Diri. 
Susanto,T. 2013. Diabetes, Deteksi,

Pencegahan, Pengobatan. Jakarta : Buku Pintar. 